\title{
Uso de historias ilustradas basadas en inteligencias múltiples con estudiantes universitarios.
}

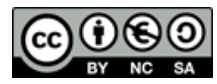

\section{Using illustrated stories based on multiple intelligences with university students}

Gilma Alexandra Gordillo Obregón. ${ }^{1}$, Ángel Paul Obregón Mayorga. ${ }^{2}$, Mónica Alejandra Logroño Becerra. ${ }^{3} \&$ Edgar Eduardo Heredia Arboleda. ${ }^{4}$

\section{Abstract.}

DOI: https://doi.org/10.33262/cienciadigital.v4i2.1210

The main objective of developing this research article is to publicize the real and didactic use of illustrated stories as a didactic instrument in University Education classrooms, following an easy, appropriate and creative way and idea to learn English that you could use in any content in the English learning process. The use of illustrated stories in a university English classroom will favor all those who are in it to create a correct atmosphere for the development of motivation, critical thinking by Atkinson (1997), and meaningful learning in Espoch university students. It is so because of this foundation that illustrated stories can be considered as a creative way of connecting student learning with society and with their real life.

All over this article, we will discover the imperative characteristics and features that may happen in the English language learning process. We investigate the benefits of using illustrated tales in university students' learning that can be settled working with multiple intelligences (MI), with artistic illustrated tales for the teaching of the English language as a didactic supply inside and outside the classroom, the ones that they will encourage the motivation, interest, and control in students. To settle, an illustrated tale was applied into an English teaching hour class in university education level to take all the important data to be investigated and to be evaluated into this research article with the important work and help of the students from the university Escuela Superior Politécnica de Chimborazo in the Renewable Natural Resources Career of the fourth semester during an English Subject II day

\footnotetext{
${ }^{1}$ Escuela Superior Politécnica de Chimborazo, Chimborazo, Ecuador, gilma.gordillo@espoch.edu.ec

${ }^{2}$ Escuela Superior Politécnica de Chimborazo, Chimborazo, Ecuador, paul.obregon@espoch.edu

${ }^{3}$ Escuela Superior Politécnica de Chimborazo, Chimborazo, Ecuador, ma_logrono@espoch.edu.ec

${ }^{4}$ Universidad Nacional de Chimborazo, Chimborazo, Ecuador, eheredia@unach.edu.ec
} 
of class in Tunshi- Ecuador to show the real importance of illustrated tales to improve Multiple intelligences and university students' learning approach based in the English learning process in university students.

Keywords: Multiple intelligences, Reading, University Education, Illustrated tales, Learning.

\section{Resumen.}

El objetivo principal de desarrollar este artículo de investigación es dar a conocer el uso real y didáctico de los cuentos ilustrados como un instrumento didáctico en las aulas de Educación Universitaria, siguiendo una manera y una idea fácil, adecuada y creativa para aprender inglés que podría usar cualquier contenido en el proceso de aprendizaje del inglés. El uso de cuentos con ilustraciones en un aula de clase universitaria de inglés favorecerá a todas las personas que están en ella para crear una atmósfera correcta para el desenvolvimiento de la motivación, el pensamiento crítico propositivo y del aprendizaje significativo en los estudiantes universitarios de la Espoch. Es así por este fundamento que, los cuentos ilustrados pueden considerarse como una forma creativa de conectar el aprendizaje del alumno con la sociedad y con su vida real. A lo largo de este artículo, descubriremos las características imperativas y que pueden ocurrir en el proceso de aprendizaje del idioma inglés. Investigamos los beneficios del uso de cuentos ilustrados en el aprendizaje de estudiantes universitarios que se pueden resolver trabajando con inteligencias múltiples (MI), con cuentos artísticos ilustrados para la enseñanza del idioma inglés como una fuente didáctica dentro y fuera del aula, los que ellos fomentarán la motivación, el interés y el control en los estudiantes. Para resolverlo, se aplicó un cuento ilustrado en una clase de horas de enseñanza de inglés en el nivel de educación universitaria para tomar todos los datos importantes que se investigarán y evaluarán en este artículo de investigación con el importante trabajo y la ayuda de los estudiantes de la Escuela Superior Politécnica de Chimborazo en la Carrera de Recursos Naturales Renovables del cuarto semestre durante un día de clase de asignatura de inglés II en Tunshi- Ecuador para mostrar la importancia real de los cuentos ilustrados para mejorar el aprendizaje de estudiantes universitarios.

Palabras claves: Inteligencias múltiples, Lectura, Educación universitaria, Cuentos ilustrados.

\section{Introducción.}

Today the imperative importance and the use of the English language all over the world has turned into a compulsory required and a prodigious challenge in a multifunctional, professionalized and globalized world for individuals. Without the use of it, communications, technology or science among countries and cultures might be problematic, being a limitation and a negative point of view for the expansion in the professional life. It is also for many other more causes that English 
language has been acquired much use inside normal life in the planet and for obvious reason in Ecuador and in the curriculum for the University Education for the development of the future young professionals in all nations around the globe. The English Language is mainly used in communication, technology and education to form global thinkers in an integral organizational dialectal, consequently cheering undergraduate and graduates a hopeful future. On behalf of this reason, the instruction of the English language is one of the most imperative topics to impart in order to yield solid bases from the very first ages of education and after the University Education teaching.

Even though it is known that Spanish-speaking people have some limits to study English with a higher level, the present research article tries to analyze these limits in education to highlight the practice of illustrated tales in the English language teaching as a supply and educational material inside the classroom in University Education. This research might be optimistic to reach a significant knowledge of another language and should stay motivational for students. It has to be known that most students from all levels of English like illustrated stories because they can be connected to their daily exists. The practice of illustrated stories in class in University Education will be emphasized by its simplicity, adaptability in didactic matters, creating many talkative, linguistic and creative abilities, consequently increasing scholar's motivation and the learning process that it is a great point of interest for all teachers of languages in the field of teaching, taking the vision proposed by Santos (1999), in which he highlights that:

"All teachers are interested in deepening their knowledge of the learning process, that is, in psychoaffective, social, educational factors, etc. that affect this process; since the more we know about this process, the better we will be able to guide teaching, in the sense that it contributes to speeding up and facilitating the use of the new language".

The present article is developed into 5 sections and it is organized as it is clarified below. The first sections define the purposes that considers reaching with the application of illustrated tales as a didactic material instrument inside an English classroom in the English subject in the University Education in the University of the Escuela Superior Politécnica de Chimborazo in Ecuador. The article involves the Literature review, which was built on the significance of Multiple Intelligences and with an educational and communicational sphere. An additional important point emphasized in the Literature review is the theme that treaties with the obstacles that Ecuador faces with English in the University Education, the diverse methodological issues that had run the Ecuadorian nation to cultivate a second language and bilingual projects in English. Subsequent this, the features of illustrated tales as an instrument for English teaching education in university and as a final point thinking on the significance of the practice of illustrated tales in the University classroom and as well as inside the curriculum of University Education in Ecuador. It is also clarified the process of the use in class with the illustrated tale and what the students will develop with the use it in a university hour class. Likewise, it establishes the contents and goals to be accomplished with the use of an illustrated story. In one of the last sections, it contains the explanation of the application of the illustrated tale in class and example activities derived from it, within a one-hour class with 
the students of the fourth semester of the Escuela Superior Politécnica de Chimborazo in the Renewable Natural Resources Career during the English normal hour class. Within this stage, important data were obtained to perform the subjective and numerical statistical research of the investigation to get conclusions and to measure the real impact of the illustrated tale with the students in the university education in the Renewable Natural Resources Career.

The tangible purpose of this research article was to verify that the use of illustrated tales in university education produces more motivation and a better individual development in the English learning process, as well as a development in the vocabulary and reading of each student; it confirms the benefits of using a tool like this inside the university classroom. However, it is important to remark that the results in this the research article reflect only in the level of the Espoch's students who helped with their participation in this research, therefore the results produced in this sampling cannot be generalized being this is a limitation along with the level of English of each university student, and the previous knowledge that will always be varied. This research article answered the following questions of investigation:

- Do they produce more motivation and meaningful English learning with the use of readings with illustrations rather than without the use of illustrated stories?

- Are there more benefits in the use of illustrated tales in the development of meaningful English language learning in the students than readings without illustrations?

\section{Justification of the problem}

The demands that a nation and a person has when is living in a globalized world have made the most spoken language in the world English. The Ecuadorian university must allow students to become people proficient of developing professionally throughout the world by teaching this important language from the first years of school. Worldwide knowledge is published in this language and that is why future professionals must develop English language 4Cs bases on, the multiple intelligences (MI) proposed by Howard Gardner (1983) in a better way to have better chances of achieving professional success. The community, social, cultural and economic problems in Ecuador have made the quality of university teaching of the English language well below the basic standards of the world for many years. As of the reform of the constitution of 2011.

On August 2011 according to law 011-0074, all students must receive five hours of English a week and the language must be taught from the first years of studies in which new standards were introduced to improve the quality of teaching and learning within university classrooms. Reversed methodologies have been developed for many years and that is why the present investigative article will serve as a great help for both professors and university students to investigate a didactic method to break with these ancient repetitious and open methodologies within the university classrooms to allow a better learning in any of the 4Cs of the English language. Global 
communication at the specialized level is a very important fact because if you acquire the English language you can be communicating with the eighty per cent of the world population, this being a competitive advantage for the rest of the professionals inside and outside Ecuador. The application of this motivating and didactic tool will help to break teaching styles and highlight what can be more visual and motivational methods for teaching university students in Ecuador. The insipient use of teaching tools in university classrooms in the teaching of the English Language makes the article a great help in creating a creative base to develop new teaching and learning tools at the level of higher education.

\section{Metodología}

To talk about the methodology used to develop this research article it has to be mentioned the model of multiple intelligences presented by Howard Gardner (1983), the one that took big importance into the article using the Verbal-linguistic intelligence using illustrate tales as a didactic material and to produce outputs that encloses oral and written language, such like an example the written essays, role plays, etc.

The article applied the reading approach for the gaining of vocabulary taken more importance the grammatical rules and. This methodology builds on the expansion of the reading skill and it is being practiced with university students.

As a first step to form several research sets for the practice of reading with illustrated stories, the students gave a placement assessment in which the mastery of the four English language skills was assessed. This test also assessed all the 4Cs, reading and English level by counting the number of words produced by the students; this test was produced by Larsen-Freeman (1978). Once the activity of reading and written evaluation with the students were completed, they were placed into two categories based on the results obtained in the written placement test; Students with a written comprehension and production of more than 150 words were put to the intermediate category, while students with a written comprehension and production of fewer than 150 words were assigned to the beginners category.

One student from each category was selected to form six groups of three and two students. The groups were categorized as follows: Group A, three students, Group B three students, Group C three students, Group D three students, Group E three students, Group F two students. Three groups were selected to take part in writing activities with the illustrated tale, while the other half participated in writing activities without the illustrated story. Each week, each group changed to a different illustrated story by performing their writing activity with an illustrated story and, without an illustrated story, and vice versa, until completing the writing process for one month activity based on Avila (2015), studies in where it is specified the optimistic influence of applying original events such as creative writing and screenwriting on enhancing EFL learners. The students used their English portfolios to collect evaluated essays with the illustrated stories and without illustrated stories. In both activities, students wrote in groups an English essay based on a particular 
English content and about important information about the tale. Each group was given fifteen minutes to organize and exchange ideas, fifteen minutes to write a draft and thirty minutes to write the final essay, in total one sixty minutes. The two groups of students met three days a week for a month and spent two hours each day as a virtual class writing their assigned compositions in a total of twenty hours of teamwork for the whole week.

To measure writing fluency by essay this study considered the method proposed by (LarsenFreeman, 1978) and (Henry, 1996), as well as the method that calculates the length of production unit proposed by Wolfe-Quintero et al., (1998) and measuring the lexical complexity using abased measure system proposed by (Ai, Haiyang and Lu, Xiaofei 2010). According to (Stein, Bernas, and Calicchia 1997) students become more reflective of their learning process during a group writing activity because they design a source of knowledge during the planning, discussion and negotiation of opinions.

\section{Resultados}

\section{Practice of English Readings}

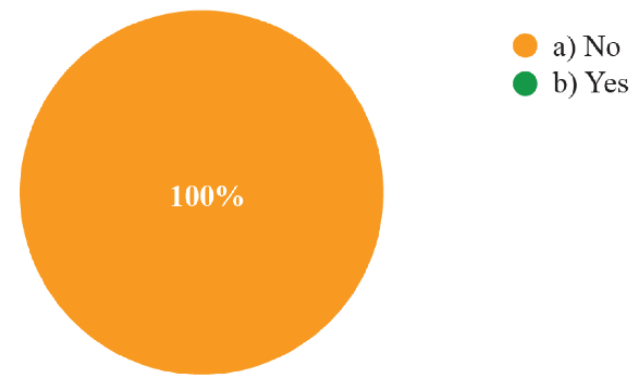

Graph 1. Practice English readings

As shown in the statistical graph 1 with $100 \%$, any student in the classroom practice English readings with 17 students of the total of the students of the class. This information allowed understanding the negative antecedent of the students for the practice of English readings.

Motivation with non- illustrated tales

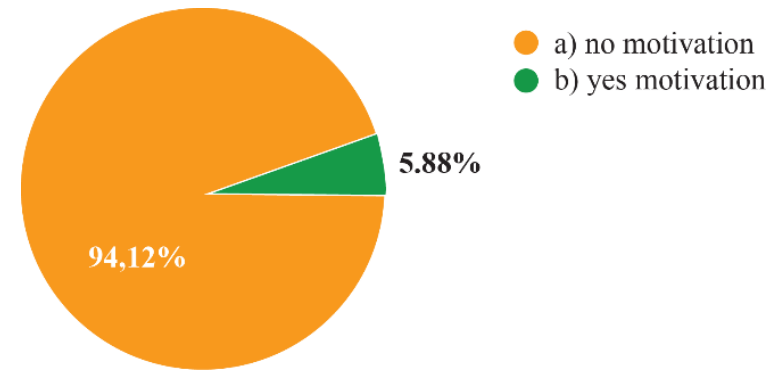

Graph 2. Motivation with none illustrated tales 
As it is presented in the statistical graph 2 with $100 \%$, any student in the classroom like to read in English readings with 17 students of the total of the students of the class. This information allowed concluding that there is a negative antecedent in the students with the likeness of English readings.

Motivation with illustrated tales

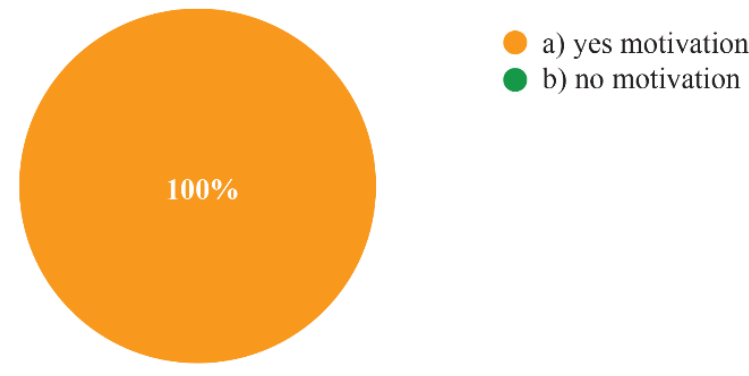

Graph 3. Motivation with illustrated tales

As shown in the statistical graph 3 with the with $100 \%$ of yes answers in students showed the motivation produced by illustrated tales in the students in comparison with the tales without them with the $0 \%$ of motivation. This information allowed concluding that the use of an illustrated tale is a good didactic tool to elevate the motivation to read and to learn English for university students with a motivation range after the application of super motivated $5.88 \%$, very motivated $29.41 \%$, motivated $58.82 \%$, little motivated $0 \%$, and nothing-motivated $0 \%$. On the other hand, the tales with no illustrations did not motivate the students in any way with $0 \%$ and all the levels of motivations above described.

Skills developed with none illustrated tales

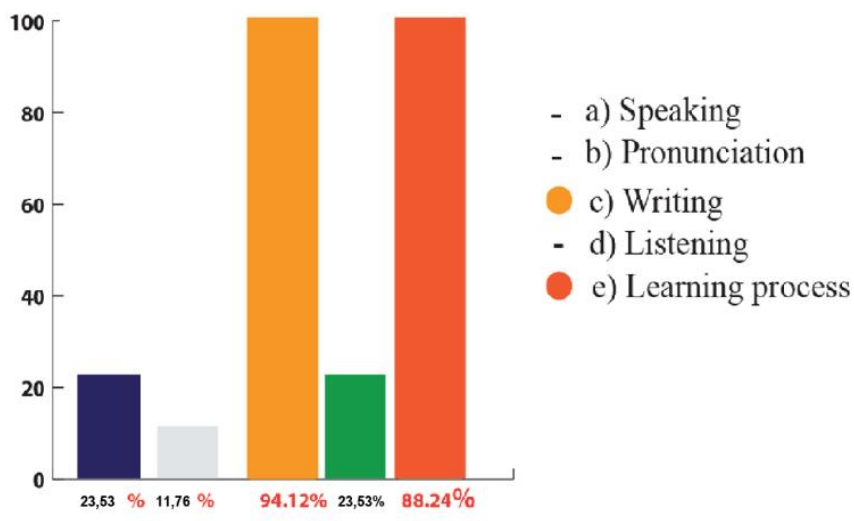

Graph 4. Opinion about the developed of English skills with illustrated tales

Graph 4 shows that the opinion of the 17 students the $100 \%$, of them think that illustrated tales help in the development of writing and in the process of learning. The other percentages are less than $50 \%$, which makes to conclude that they are not benefits to be taken for the English learning process. 
Skills developed with non-illustrated tales

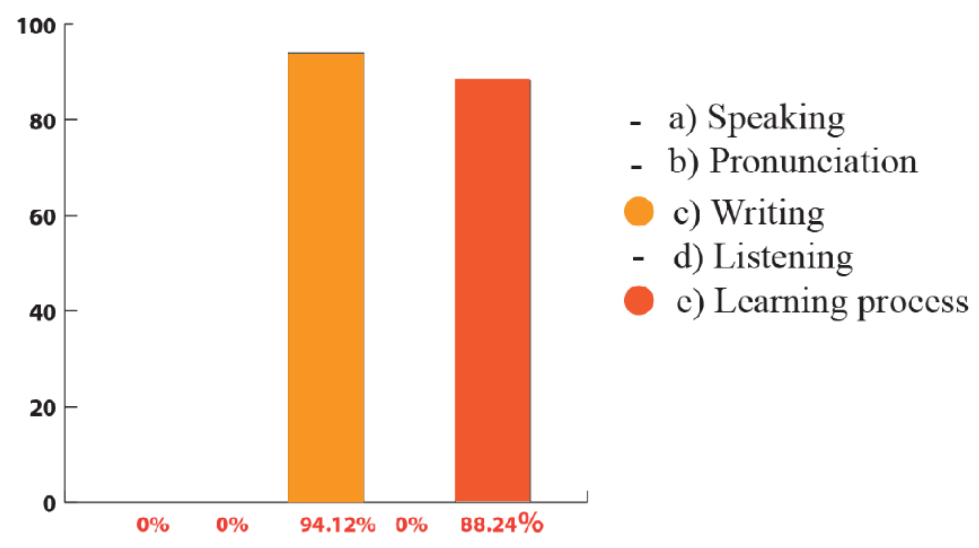

Graph 5. Opinion about the developed of English skills with none illustrated tales

As shown in the statistical graph 5, about the use of tales with no illustration in the statistic graph 5 , it is shown the students opinion about the tales with no graphics or illustrations. These percentages are also important and relevant to be an outstanding help in the development of the writing with $94.12 \%$, less than the illustrated tales is, but also important. The second important percentage is the help in the learning process with an $88.24 \%$ important data that also is less than the use of the illustrated tales, but to be more than $50 \%$ as an important conclusion to be taken in the use of the tales with no illustrations in class. The other proportions like speaking, pronunciation, and listening are less than 50\% what gave us the conclusion that they are not benefits to be taken as a help for the English learning process with this tool.

Development English with Illustrated tales

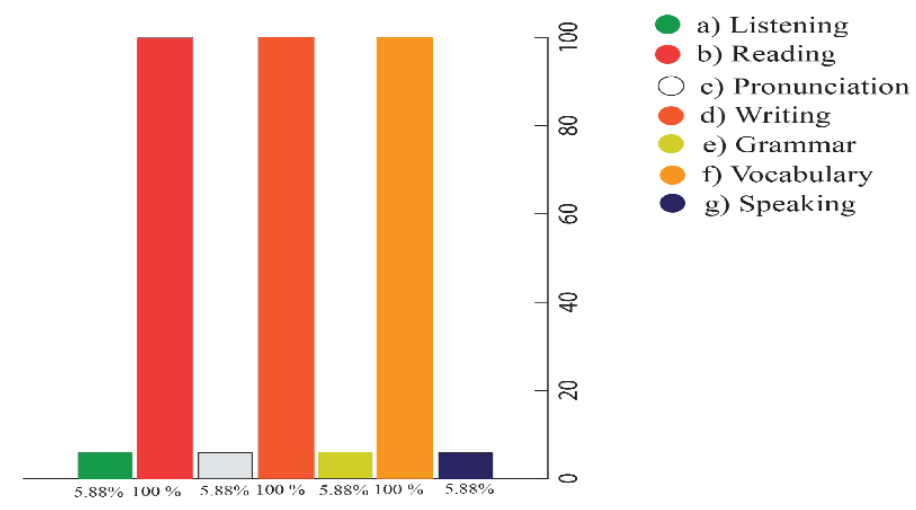

Graph 6. Conclusion of the developed of English skills with illustrated tales in class

As shown in the statistical graph 6,100\%, of the student in the classroom thought that reading, writing and vocabulary were the aspects of English that they have developed individually with the application of illustrated tales in class. The evidence allowed to determinate the positive and real 
acceptation of illustration tales as a didactic tool to improve English teaching and learning in special in these three aspects of the language the reading, writing and vocabulary. The other proportions like speaking, grammar, pronunciation, and listening are less than $50 \%$ what gave us the conclusion that they are not benefits to be taken for the English learning process with this tool.

Development of English with non-illustrated tales

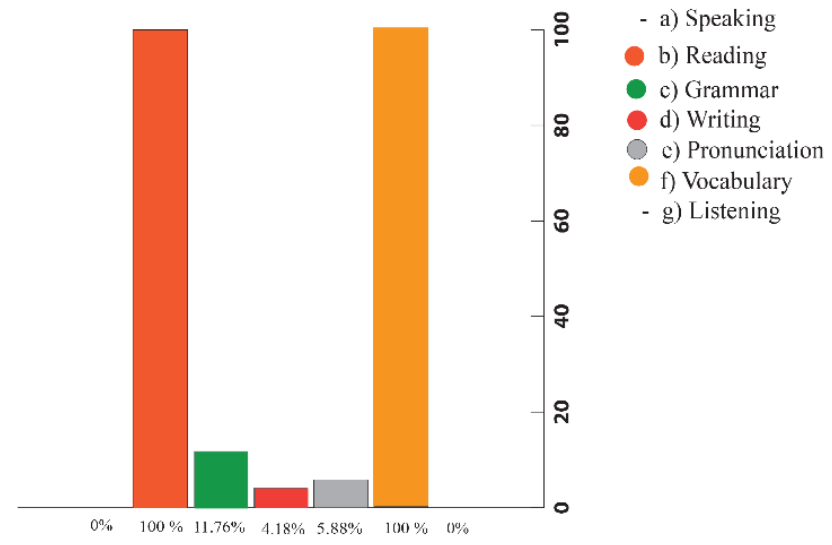

Graph 7. Conclusion of the developed of English skills with non-illustrated tales in class

As shown in the statistical graph 7 in which shows that the $100 \%$, of the 17 students in the classroom thought that reading and vocabulary were the aspects of English that they had developed individually with the application of tales with no illustrations in class. The students' opinion is evidence allowed to determinate the positive and real acceptation of illustration tales as a didactic tool to improve English teaching and learning in special in these two aspects of the language the reading, writing and vocabulary. In comparison with the percentages of the application with illustrated tales, the students have more acceptation when they used tales with illustration rather than no graphs inside. The other proportions like speaking, grammar, pronunciation, and listening are less than $50 \%$ what gave us the conclusion that they are not benefits to be taken for the English learning process with this tool.

Grading assessment output with illustrated tales and non- illustrated tales

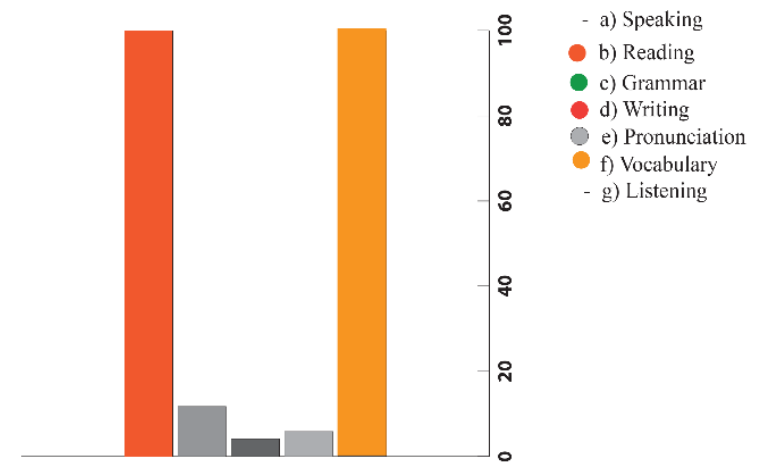

Graph 8. Out-put Grading arithmetic mean and media with illustrated and non-illustrated tales 
As shown in the statistical Graph 8, in which shows that it can be settled after qualifying the written task four times during one month that the Arithmetic means of the student's assessments is 9 out of 10 points with the use of illustrated stories and 7 out of 10 points with the use of non-illustrated stories. With these results, it is shown that the use of illustrated stories improved academic performance in a better way, obtaining the best grade with the use of illustrated stories. The percentage of improvement of the stories not illustrated is also important and positive, but comparing between the use of illustrated and non-illustrated stories, the first results a greater benefit in academic performance obtaining better grades with an arithmetic media of 8.83 out of 10 points a comparison with the non-illustrated stories with 8 out of 10 points. To close, the arithmetic media obtained a greater positive difference in comparison with the practice of illustrated stories with a 9 out of 10 points compared with a 7.5 out of 10 points with the use of stories without illustrations, coming to understand that the use of illustrated stories helped students in a better way.

In addition, it can be settled after qualifying the written task four times during a month that the Statistical Mode with a 9 out of 10 points with the use of illustrated stories and 7 out of 10 points with the use of non-illustrated stories. By these results, it is shown that the use of illustrated stories improved academic performance in a better way, obtaining best grades over 10 points with the use of illustrated stories. The percentage of improvement of non illustrated stories is also important and positive, but comparing between the use of illustrated tales and non-illustrated stories, the first results provided a greater benefit in academic performance obtaining better grades using an arithmetic mean of 8.83 over 10 points in comparison with the non-illustrated stories with 8 out of 10 point. To complete, the Arithmetic Media obtained greater and a positive difference using illustrated stories with 9 out of 10 points compared with 7.5 out of 10 points with the use of stories without illustrations, coming to understand that the use of illustrated stories in class helped students better.

The Chi-square test was performed to verify important data such as a level of significance of the variables having a 0.01 or $1 \%$, with a degree of freedom of 1 , a level of significance of $95 \%$, a parametric value of $\mathrm{p}$ of 0.09 and a critical value of 1.96 . With this information, we can conclude that the use of illustrated stories directly influences the process of English teaching-learning and the different multi intelligences in the university students studied.

\section{Discussion}

The highest determination of this article is to include the university student's contribution in their learning process in a motivating way and stimulating their knowledge with their sense of right and wrong to learn through the reading with illustrated tales. Thus, the research article was founded on a communicative didactic methodology with the use of illustrated tales, in which teachers turn on their role applying a Competency-Based Language Teaching (CBLT) which are proposed by Richards \& Rodgers (2001), to support the English learning process founded in the language and 
the content, where the main aim of use of the illustrated tale was to develop the university student's skills and their multi intelligences, to elevate the learning process in university students.

The combination of a didactic tool such as illustrated tales with an example communicative written outcome approach and the Multiple intelligences have been useful to elevate the learning process in the university students in fourth semester of the Escuela Superior Politécnica de Chimborazo in their First level of English in Ecuador and also it is a great useful educational tool in the English teaching process in the university education.

This investigation also used a written activity, where the teacher presented a written task to put in action utility of the illustrated tales proposed by Cofer, Appley (1964), in their theory of motivation with the university students as an outcome task. Any output formulated on English content is a great help for learners during the process of learning better English. The future task has to be based on important information from the tale applied in class. Many activities originated from English content can be developed with illustrated tales, in which each student has the same opportunity to learn and to develop their own multiple intelligences learning processes in a different way.

Talking about illustrated tales to develop the 4Cs, (MI) multi intelligences ideas with an outcome has played the most important role in the article, seeing the English language of, for and through learning. With any activity designed related to the English content, the students will be able to stimulate the practice of the language, autonomously, and to improve their higher order of critical thinking propose by (Saleh, 2019), and to the knowledge in its construction. This research article has thought to be applied in a University Education level in the English Language at any level and focusing on the multiple intelligences to help the learning process increase in university students in Ecuador. The output activities and the English contents have to be a clue for the correct application in the class based on Halvorsen (2005) and Araidne (2017), highlighting the part of the teacher in giving the necessary tools and tasks for developing critical thinking and generating good environments with didactic activities. The methodology proposed could be modified to many English contexts or level of English even also to Secondary level of English Education, where students with a certain level of autonomy and skills fold many experiences and more informational synthesis.

To complete, the article was made to create awareness of all the multiple intelligences in university learners and teacher to make the university learning process.

Totally, the strategies of teaching and learning are always an excellent and exceptional learning didactic tool, which provides great support and help to the meaningful learning in university students and to the growth for the accomplishment of educational goals and results. Contrariwise, different characters and ways of learning from personal and between learners make it truly problematic to use all teaching strategies for a particular category of activity as for other sensory channels. Therefore, it is established that the learning strategies may be applied according to the personal individualities of the learners and also the groups of students or the class and the by 
Howard Gardner (2006), in his wonderful point of view when talking about separate skills or abilities, known as Multiple Intelligences talking about global applications of them in the class. As a deduction, it can be said that illustrated tales produce more motivation and meaningful learning with the use of a graphical description rather than tales without the use of illustrations, developing a higher average of meaningful English learning in the university students.

\section{Conclusiones.}

- To give a conclusion, it can be alleged that the objective of this study has been to scope the utility of the theory that speaks about MI to design and to apply new learning strategies such as the illustrated stories for university students in Ecuador in an English hour class from a theoretic perception to increase the students learning process of the English language in a university classroom.

- The presentation of illustrated tales in university class will affect definitely positively in more average in students and teachers that may have to adjust to a great modification in their teaching and their learning methodology. A big adjustment in the way of thinking, in the method of to give to receive content, information and assistance to university students.

- The way to provide an educational activity may always be linked to the English content and language, and how the pupils can be assessed in different methods with activities and incomes for teaching.

- The Multi Intelligences (Gardner, 1994), can be applied in numerous ways, with the use new educational methods of training and learning in the university classroom; knowing that IMs allow the implementation of them with no difficulties, elevating the English learning process in learners.

- An active and autonomous student includes all the majority of intelligences that may exist in their learning process. An important aspect the use of the visual communication provision to university students in the learning process based on imaginative thinking with the real-world use and final production inside and outside the classroom encourages the imagination and the critical thinking in students.

- In order to assess the research article, information was taken before and after to be analyzed with statistics. To conclude, a process of tabulation and statistics for the evaluation carried out the conclusions for the finalization of the research article.

- It can be concluded that this research article assessed the use of illustrated tales to improve positively in a higher way the motivation, multiple intelligences and the students' learning approach having benefits in the writing, vocabulary and reading having a better acceptance in comparison with the use of tales with no illustrations; concluding that illustrated tales are a huge educational supply for the English teaching and learning process in the university students of the Escuela Superior Politécnica de Chimborazo in the Renewable Natural Resources Career of the fourth semester in Ecuador. 


\section{Referencias bibliográficas.}

Ai, Haiyang and Lu, Xiaofei (2010). A web-based system for automatic measurement of lexical complexity. Paper presented at the 27th Annual Symposium of the Computer-Assisted Language Consortium (CALICO-10). Amherst, MA. June 8-12.

Atkinson, D. (1997). A Critical Approach to Critical Thinking in TESOL TESOL Quarterly, Vol. 31. 71-94. Retrieved from: URL: http://www.jstor.org/stable/3587975

Avila, H. (2015). Creativity in the English class: activities to promote EFL learning. HOW, 22(2), pp. 91-103. ISSN 0120-5927

Cofer, C. N., \& Appley, M. H. (1964). Motivation: Theory and research. John Wiley.

Ecuador, R. O. (2011). Retrieved from: Ley Orgánica de Educación Intercultural: https://www.wipo.int/edocs/lexdocs/laws/es/ec/ec023es.pdf

Gardner, H. (1983). Frames of Mind: The Theory in the following way. New York: Basic Books.

Gardner, H. (1994). Estructura de la Mente: Teoría de las inteligencias múltiple. México. Paidós.

Gardner, H. (2006). Multiple Intelligences. New horizons. New York: Basic Books.

Halvorsen, A. (2005). Incorporating Critical Thinking Skills Development into ESL/EFL Courses

Larsen-Freeman, D. (1978). An ESL Index of Development. TESOL Quarterly, 439.

Richards, J., \& Rodgers, T. (2011). Approaches and Methods in Language Teaching. Cambridge: Cambridge University Press: 148.

Saleh, E.S. (2019). Critical thinking as a 21st century skill: conceptions, implementation and challenges in the EFL classroom. European Journal of Foreign Language Teaching, Vol.4 (1), pp. 1-16. Available on-line at: www.oapub.org/edu

Santos, I. (1999): Lingüística aplicada a la enseñanza/aprendizaje del español como lengua extranjera. Madrid, Arco/Libros.

Stein, N. L., Bernas, R. S., \& Calicchia, D. (1997). Conflict talk: Understanding and resolving arguments. In M. Noonan \& T. Givón (Eds.), Conversation: Cognitive,

Wolfe-Quintero, K., Inagaki, S., \& kim, H.-Y. (1998). Second Language Development in Writing:Measures of Fluency, Accuracy and Complexity. Manoa: Richard Schmidt. 
PARA CITAR EL ARTÍCULO INDEXADO.

Gordillo Obregón, G. A., Obregón Mayorga, Ángel P., Logroño Becerra, M. A., \& Heredia Arboleda, E. E. (2020). Uso de historias ilustradas basadas en inteligencias múltiples con estudiantes universitarios. $\quad$ Ciencia $\quad$ Digital, $\quad 4(2), \quad$ 88-101. https://doi.org/10.33262/cienciadigital.v4i2.1210

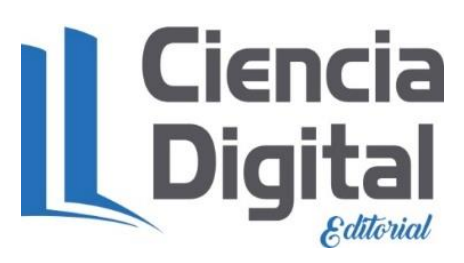

El artículo que se publica es de exclusiva responsabilidad de los autores y no necesariamente reflejan el pensamiento de la Revista Ciencia Digital.

El artículo queda en propiedad de la revista y, por tanto, su publicación parcial y/o total en otro medio tiene que ser autorizado por el director de la Revista Ciencia Digital.
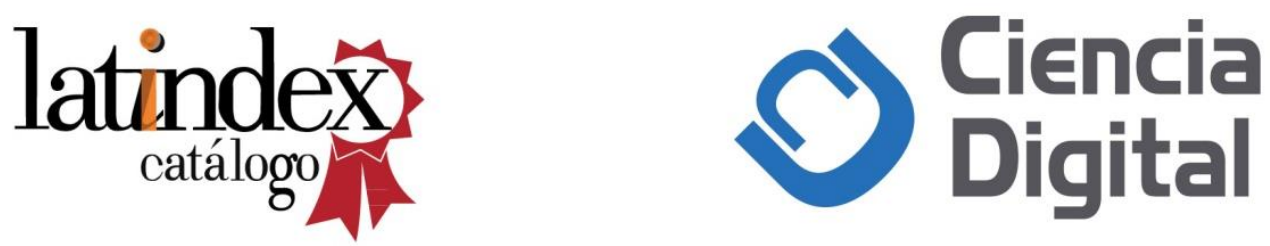